\title{
LIVESTOCK SITUATION AND PROBLEMS IN FERGANA REGION
}

\author{
Djuraev Ravshan Xurramovich \\ $P h D$ researcher of National University of Uzbekistan
}

Article DOI: https://doi.org/10.36713/epra4072

\begin{abstract}
Since ancient times, the field of livestock was one of the important economic sectors of every nation and was considered the main factor in the economic development of society and the state and ensuring the welfare of the nation. The natural geographical location of Fergana region is a favorable territory for the development of cattle breeding and has made achievements in this area in the past. As a result of the occupation of the Soviet state in this area, a certain difficulty arises. First of all, the well-being of livestock, of course, will be directly related to the fact that there will be enough fodder. Archive materials testify that in the 30-40-ies of the XX century in the Ferghana region there was a decrease in the number of large-horned moles. This is caused by a lack of fodder in the first place. This situation is especially evident in the Fergana region, where irrigation farming has developed [Central State Archive of Uzbekistan. 837-fund, 32-list, 3066-case. 8-9-sheets].
\end{abstract}

\section{DISCUSSION}

Since ancient times, the field of livestock was one of the important economic sectors of every nation and was considered the main factor in the economic development of society and the state and ensuring the welfare of the nation. The natural geographical location of Fergana region is a favorable territory for the development of cattle breeding and has made achievements in this area in the past. As a result of the occupation of the Soviet state in this area, a certain difficulty arises. First of all, the well-being of livestock, of course, will be directly related to the fact that there will be enough fodder. Archive materials testify that in the 30-40-ies of the XX century in the Ferghana region there was a decrease in the number of large-horned moles. This is caused by a lack of fodder in the first place. This situation is especially evident in the Fergana region, where irrigation farming has developed [Central State Archive of Uzbekistan. 837-fund, 32-list, 3066case. 8-9-sheets].

The dynamics of cattle breeding in the Fergana region is reflected in the archival documents as follows. In particular, if in 1939 year in the region there were 431.1 thousand large horned goods, it can be seen that in 1940 large horned goods decreased by $6.4 \%$ compared to the same period of the year. However, small-horned, in particular sheep and goats, grew by $1939 \%$ in 1940 compared to 8.8 years. It should be noted that the slow growth in the number of large-horned cattle, sheep and goats in the Fergana region is influenced not only by their low cultivation, but also by the fact that they are much slaughtered in meat[Central State Archive of Uzbekistan 837-fund, 32-list, 3066-case. 16-sheet]

In the balance of meat products of the regions of the Uzbek SSR, the types of livestock were not the same. In the gross production of meat in Tashkent and Fergana regions, sheep and goats played a key role, if the population of these regions was associated with the need to consume meat products, the number of sheep and goats would not have increased. Despite the fact that their meat was consumed a lot, the increase in its number was high in these regions, and the increase in the number of cattle was unsatisfactory .

As a result of the lack of feedings in Uzbekistan, the army had to feed livestock in the regions of the republics. In particular, the feeding of sheep of Fergana region in the Kyrgyz SSR significantly helped to solve problems related to fodder, and The Tashkent region has its own pasture, in addition, the Kazakh SSR has also been used. Therefore, sheep and goat farming in these two regions is well developed, not well developed because there is not enough fodder for cattle[Central State Archive of Uzbekistan 837-fund, 32-list, 3072case. 9-sheets] 


\section{SJIF Impact Factor: 6.260| ISI I.F.Value:1.241| Journal DOI: 10.36713/epra2016

More than 100 percent of the meat used for consumption was made up of more than the cattle used for herd breeding. Thus, in the Fergana region, only 3,4 percent remained in the herd, as the bulk of the cattle went to meat production.

The main feed for this type of livestock is irrigated farming products, the feed grown in 1940 year was not enough . In 1940, the state increased the meat supply, because the state was obliged to hand over meat to noncommissioned farms, and a large part of the meat produced for consumption was made up of meat handed over to the state.

Despite the existence of various in the region, the increase of young livestock also focused attention. 1940 year in the herds of the collective farm 100 calves born of female animals-63.1 thousand heads, lambs45.8 thousand, and the number of patches-71.3 thousand heads.

But the plans for the restoration of their herds in the kolkhozs in the region were not fulfilled.In September 1940, the Central Committee of Uzssr and KP(b) adopted a decision on the purchase of 56.1 thousand head cattle and 95 thousand head sheep and goats. In this decision, there was a detailed discussion of the shortcomings in this area.

It is worth noting that in a short time there were specific disadvantages to the purchase of livestock at a speed. First, it was not possible to conduct a medical examination of the PET, which was bought at a short time. Secondly, when buying urgently, the quality of the pet was not paid attention. In the execution of the plan in this way, no attention was paid to the sex and age composition of the cattle, especially when buying cattle, these aspects should be paid attention.[ Central State Archive Of The Republic Of Uzbekistan. 90stock, 8-list, 1717-work. 6-sheet]

As a result, $1 / 3$ of the purchased cattle consisted of calves up to the age of 1 year, and in their composition, too, the husks formed the majority:

As a result of such a purchase, some collective farms will only have a minimum number of cows at the end of 1942 year, that is, they will not be able to fulfill the state's milk plan even by 60 percent. The failure of the collective farm purchase plan by the collective farms was also the reason for the inadequate provision of agricultural credit. The plan for breeding sheep and goats was fulfilled only by the Karakalpakstan ASSR. In particular, the Fergana and Khorezm regions were behind the implementation of the plan in this regard and were concerned with the low birth rate of cattle in them, as well as the depletion of adult cattle. The zootechnical work was also in an unsatisfactory state. For this reason, it was not considered with great interest to feed cattle in relation to sheep breeding and goat breeding in the Republic collective farms.

1940 Year January 168 collective farms each had more than 35 cigarettes, but their number was reduced to $1 / 4$ part. For example, in 1939 in 3 regions of the Republic (Tashkent, Fergana and Samarkand) cattle consumption amounted to 27.9 thousand heads, of which 11 thousand cattle or 39.4 percent were transferred to the state. In 1940 , in these three regions, this figure reached 43.5 thousand heads, of which 23.8 thousand cattle or 66.2 percent were transferred to the state. Kolkhoz basically tried to carry out the transfer of meat to the state on the account of cattle.

The market price per kilogram of live weight of sheep is estimated at 30-40 percent higher than that of cattle. Therefore, a number of collective farms handed cattle to the state, sold sheep on the market, and instead bought cattle from the market and transferred meat to the state [Central State Archive Of The Republic Of Uzbekistan. 90-stock, 8-list, 3089-work. 6-sheet]

As a result, in some regions, including Fergana region, cattle were 96.3 per cent in the transfer of livestock to the state in 1940. In other regions of the Republic, too, such a situation could be seen. The decrease in the contribution of sheep and goats in the transfer to the state also negatively affected the abolition of the privileges granted to sheep in 1940 year. In the 1940s, the livestock to the state increased significantly compared to the 1939 year, firstly the meat plan was increased, and secondly, other taxes were also replaced by livestock. [Central State Archive Of The Republic Of Uzbekistan. 90-stock, 8-list, 1717-work. 6-sheet]

The decision of the Economic Council of the XKS of the USSR to prohibit the adoption of cattle weighing below average weight belonged to collective farms, which had nothing to do with collective farmers. The weight of the pet handed over by the collective farmers was generally not in demand. Lower-weight pet of the average weight was as follows in relation to the total pet filed (according to the live weight): The main reason for the low weight of the cattle entrusted by the collective farmers was the lack of nutrients. Work on the organization of livestock farms in collective farms was carried out in 1939 year, in 1940 year, attention was paid to their strengthening. But in 1940 year again continued to create new livestock farms. In 1941 year on 1 January, each collective farm amounted to 2,4 units of livestock. In 1940, the number of collective farms of 2 and 3 Increased. Kolkhozs did not fully fulfill the decision of the Central Committee of the USSR HKS and VKP (b) on 8 July 1939 year, about a third of kolkhozs fulfilled this decision, 20 percent of kolkhozs did not have farms at all, in these kolkhozs did not even allow the provision of herded cattle by one type of livestock. The best results were obtained by QQ ASSR when providing herds with livestock, where there were 2 and 3 farms with the minimum number of female cattle, which were established in almost half of collective farms. The number of cows in particular in the CCP livestock farms of Uzbekistan was lacking. In 1940 Year of the Republic collective farms had a total 
of 43.9 thousand cows, of which 16.6 thousand cows would have come to the account of collective farms that fulfilled the set minimum. Thus, there were a total of 27.3 thousand cows in collective farms that were below the set minimum. Uzbekistan accounted for $60 \%$ of 90,8 thousand head cows in the USSR, from which 5.6 thousand head cows were in the collective farms that fulfilled the plan[Central State Archive of the Republic of Uzbekistan 837-fund, 32-list, 2331-work. 8-Sheet] In conclusion, the policy carried out in the field of livestock in the 30-40-ies of the XX century in the Fergana region was not left without showing its impact on its condition. In this regard, it is desirable to conduct a thorough scientific research on this topic. 